\title{
Reduction of rat prostate weight by combined quercetin-finasteride treatment is associated with cell cycle deregulation
}

\author{
Zengshuan Ma, Thanh Hung Nguyen, Thanh Hoa Huynh, \\ Phuc Tien Do and Hung Huynh
}

Laboratory of Molecular Endocrinology, Division of Cellular and Molecular Research, National Cancer Center of Singapore, Singapore 169610 (Requests for offprints should be addressed to Hung Huynh; Email: cmrhth@nccs.com.sg)

\begin{abstract}
Benign prostate hyperplasia and prostate cancer are major public health problems. We report herein that daily treatment of male rats with 50,100 or $150 \mathrm{mg}$ quercetin per $\mathrm{kg}$ body weight resulted in serum concentrations of quercetin equivalent to $25 \cdot 3 \mu \mathrm{M}, 43 \cdot 3 \mu \mathrm{M}$ and $54 \cdot 3 \mu \mathrm{M}$ respectively. Concomitantly, serum testosterone levels were increased by $1 \cdot 79-, 1 \cdot 83$ - and $3 \cdot 48$-fold, while serum dihydrotestosterone (DHT) levels were 125\%, 92\% and $73 \%$ of the control. A slight increase in prostate weight coupled with dilated prostate lumens full of secretory materials were observed. Finasteride alone caused a significant decrease in serum DHT level and prostate weight. Co-administration of quercetin with finasteride prevented the finasteride-induced decrease in serum DHT levels but significantly enhanced the reduction in wet prostate weight, which was reduced by $26.9 \%$ in finasteridetreated animals to $31 \cdot 8 \%, 40 \cdot 0 \%$ and $48 \cdot 2 \%$ after fina-
\end{abstract}

steride given together with the three doses of quercetin. The combined treatment altered cell cycle-regulated proteins in a wide spectrum. The expressions of cyclin D1, CDK-4, cdc-2 and phospho-cdc-2 at tyrosine 15, phospho-MEK1/2, phospho-MAP kinase, phospho-pRb at serine 780 and serine $807 / 811$ were significantly inhibited, while the levels of p15, p21 and p27 were increased. In conclusion, quercetin-finasteride treatments caused wide cell cycle deregulation in rat prostates, which, in turn, decreased the proliferation rate, changed the secretion activities of epithelial cells and resulted in a marked reduction in wet prostate weight. The results suggest that quercetin synergizes with finasteride to reduce the wet prostate weight through a cell cyclerelated pathway, which may be androgen independent.

Journal of Endocrinology (2004) 181, 493-507

\section{Introduction}

Benign prostate hyperplasia $(\mathrm{BPH})$ and prostate cancer are major public health problems (Stoner 1994). The aim of palliative treatment of $\mathrm{BPH}$ or prostate cancer is to downregulate the levels of circulating androgen or to block the transcription, activation and function of the androgen receptor, or both. Finasteride acts as a competitive and specific inhibitor of $5 \alpha$-reductase, resulting in suppression of serum and intraprostatic dihydrotestosterone (DHT) concentrations to castrated levels, with subsequent reduction in prostatic size (The Finasteride Study Group 1993, Rittmaster 1994). Finasteride is approved for treatment of symptomatic BPH (Feigl et al. 1995). The only clinically significant side effects of finasteride are related to sexual function such as decreased libido and impotence (Stoner 1994).

Androgen plays a critical role in the growth, maintenance and function of the normal prostate gland (Cunha et al. 1987). Androgen-deprivation therapy causes marked and characteristic changes in normal prostate and in prostate cancer (Murphy et al. 1991, Ferguson et al. 1994).
The biological function of androgen in the prostate is mediated by the androgen receptor (AR). Activation of the AR leads to complex proliferative, apoptotic and angiogenic events, which are mediated by interaction with a series of co-activators and a smaller subset of corepressors (Lu et al. 1999, Gregory et al. 2001, Petre et al. 2002). The mitotic signal of androgens is thought to target ultimately the cell cycle machinery (Yamamoto et al. 2000). Androgen stimulates the expression of the cell cycle genes CDK-1, CDK-2 and CDK-4 and increases the levels of cyclin A and cyclin B1 mRNAs (Lu et al. 1997, Gregory et al. 2001). The cyclin-dependent kinase (CDK) kinase activities can be further increased by repressing the expression of CDK inhibitor p16 gene (Lu et al. 1997), overexpressing phosphatase cdc25B (Ngan et al. 2003) or binding to cyclin E (Akita et al. 2001). Cyclin E has been reported to associate with AR to potentiate its activity in prostate cancer (Yamamoto et al. 2000). Although studies have also established the functional link of AR with cyclin $\mathrm{D} 1$ (Petre et al. 2002) and $\mathrm{p} 21$ (Lu et al. 1999), the multiple roles they play in cell proliferation, differentiation, and apoptosis are still intriguing. Cyclin D1 may 
play a mitogenic role (CDK-4-dependent) and an antimitogenic role (dependent on regulation of the AF-1 domain) that can collectively control the rate of androgendependent cellular proliferation (Petre et al. 2002).

On the other hand, epidemiological studies have shown that the consumption of vegetables, fruit and tea is associated with a low risk of cancer (Steinmetz \& Potter 1991, Yang \& Wang 1993). Quercetin, one of the most common flavonoid glycones, has a wide range of biological activities including inhibition of protein kinase C (Agullo et al. 1997), tyrosine kinase (Akiyama et al. 1987), phosphatidylinositide 3-kinase (PI-3 kinase) (Agullo et al. 1997) and DNA topoisomerase II (Constantinou \& Huberman 1995). Importantly, quercetin has antiproliferative activity in vitro against several cancer cells by inhibiting the expression of cyclin A (Yoshida et al. 1992), cyclin B1 (Choi et al. 2001), cyclin D1 (Kaneuchi et al. 2003), cdc2 (Choi et al. 2001, Yoshida et al. 1992) and CDK-4 (Bhatia et al. 2001). Treatment with quercetin arrests cell cycle progression either at the G1/S phase (Bhatia et al. 2001) or at the G2/M transitional boundary (Choi et al. 2001). In vivo synergy of quercetin with cisplatin against a lung cancer xenograft has been reported (Hofmann et al. 1988). Quercetin also inhibits cell invasion and induces apoptosis through a pathway involving heat shock proteins (Wei et al. 1994). Although the mechanisms of the antiproliferation effects of quercetin remain to be illustrated, there is evidence suggesting that the action of quercetin is probably mediated by interaction with the type II estrogen binding sites (Ranelletti et al. 1992) or the aryl hydrocarbon receptor (Ashida et al. 2000). These activities of quercetin make it a promising candidate for the treatment and prevention of various cancers including prostate cancer.

The cell cycle-regulated proteins are considered to be the common downstream effectors mediating the effects of finasteride and quercetin in the prostate gland. In this study, we report that quercetin when co-administered with finasteride prevented finasteride-induced changes in serum DHT levels, but caused reduction in wet prostate weight. The combined effects of quercetin and finasteride on wet prostate weight were associated with their ability to modulate the expression of cell cycle-regulated proteins. The expressions of cyclin D1, CDK-4, cdc-2 and phosphocdc-2 at tyrosine 15, phospho-mitogen extracellular kinase 1/2 (MEK1/2), phospho-MAP kinase (MAPK), phospho$\mathrm{pRb}$ at serine 780 and serine $807 / 811$ were significantly down-regulated while the levels of p15, p21 and p27 were increased. The combined treatment also significantly reduced the ratio of hyperphosphorylated $\mathrm{pRb}$ to total $\mathrm{pRb}$.

\section{Materials and Methods}

\section{Reagents}

Rabbit anti-phospho MEK1/2 (Ser217/221), mouse antiphospho p44/42 MAP kinase (Thr202/Tyr204), rabbit anti-cdc-2, rabbit anti-phosphorylated cdc-2 (Tyr15), mouse anti-retinoblastoma (pRb), rabbit antiphosphorylated pRb (Ser780), rabbit anti-phosphorylated pRb (Ser795), rabbit anti-phosphorylated pRb (Ser807/ 811) and rabbit anti-phospho-Akt-1 (Ser473) antibodies were purchased from New England BioLabs (Beverly, MA, USA). Rabbit anti-ERK-1, rabbit anti-p85 subunit of PI-3 kinase, mouse anti- $\alpha$-tubulin, rabbit anti-cyclin A, rabbit anti-epidermal growth factor receptor (EGFR), rabbit anti-Raf, rabbit anti-pRaf, rabbit anti-cyclin B1, mouse anti-cyclin E, mouse anti-cyclin D1, mouse antiCDK-2, rabbit anti-CDK-4, mouse anti-CDK-6, mouse anti-p21, mouse anti-p27 and mouse anti-p15 antibodies were from Santa Cruz Biotechnology (Santa Cruz, CA, USA). Mouse anti-Ki-67 was from NeoMarkers Inc. (Fremont, CA, USA). Anti- $\alpha$-tubulin antibody was used at a final concentration of $0.5 \mu \mathrm{g} / \mathrm{ml}$. Other antibodies were diluted into Tris-buffered saline Tween 20 (TBST) solution at a final concentration of $1 \mu \mathrm{g} / \mathrm{ml}$, as recommended by the manufacturers.

\section{Animals}

Animals were maintained and treated according to the guidelines of the Local Animal Care Committee. Ten-week-old male Sprague-Dawley rats, provided by the Animal Holding Unit, National University of Singapore, were divided into 8 groups $(n=8)$. To test the effect of quercetin on rat prostate, rats were daily gavaged with quercetin (Sigma, St Louis, MO, USA), dissolved in 5\% dimethyl sulfoxide (DMSO) aqueous solution, at a dose of 50,100 or $150 \mathrm{mg}$ per $\mathrm{kg}$ body weight $(\mathrm{BW})$. To block the conversion of testosterone to DHT, one group of rats was treated daily with finasteride $1 \mathrm{mg} / \mathrm{kg} \mathrm{BW}$ (5 mg/tablet, Merck Frost, Quebec, Canada) by gavage. We have previously reported that at this dose the weight of the prostate was reduced to $80 \%$ of the control, while the DHT level was decreased to $39 \cdot 5 \%$ and the testosterone level was increased 2.4-fold as compared with the control (Huynh et al. 1998). To investigate the combined effects of quercetin and finasteride on prostate weight and serum androgen levels, rats were treated daily with $1 \mathrm{mg}$ finasteride $/ \mathrm{kg} \mathrm{BW}$ plus 50,100 or $150 \mathrm{mg}$ quercetin $/ \mathrm{kg}$ $\mathrm{BW}$. Control rats received the same dose of vehicles. To determine the concentration of quercetin in the serum, the rats were immobilized in a restraint device at $4 \mathrm{~h}$ post drug administration and the blood was collected with a 23gauge needle after the tail vein was slightly enlarged by mopping with $70 \%$ alcohol. After 10 days of treatment, animals were weighed and killed, and wet prostate, pancreas, liver, kidney, testis and serum were collected. After weighing, a portion of the prostate, together with other tissues, was fixed in $10 \%$ buffered formalin for paraffin embedding; the remaining tissue was immediately frozen in liquid nitrogen for further analysis. 
Table 1 Effects of quercetin (Q; 50, 100, $150 \mathrm{mg} / \mathrm{kg}$ ), finasteride (F; $1 \mathrm{mg} / \mathrm{kg}$ ) and finastride plus quercetin $(F Q)$ on the body weight, wet prostate weight, serum testosterone and dihydrotestosterone (DHT) levels of rats (means \pm S.E.M., $n=8$ )

\begin{tabular}{|c|c|c|c|c|}
\hline \multirow[b]{2}{*}{ Treatment } & \multirow[t]{2}{*}{$\begin{array}{l}\text { Body weight } \\
\text { (g) }\end{array}$} & \multirow[t]{2}{*}{$\begin{array}{l}\text { Wet prostate weight } \\
(\mathrm{mg})\end{array}$} & \multirow[t]{2}{*}{$\begin{array}{l}\text { Serum testosterone } \\
(\mathrm{ng} / \mathrm{ml})\end{array}$} & \multirow[t]{2}{*}{$\begin{array}{l}\text { Serum DHT } \\
(\mathrm{pg} / \mathrm{ml})\end{array}$} \\
\hline & & & & \\
\hline Control & $343 \cdot 7 \pm 7 \cdot 6$ & $455 \cdot 0 \pm 15 \cdot 5^{a}$ & $1 \cdot 79 \pm 0 \cdot 29^{a}$ & $227 \cdot 9 \pm 19 \cdot 9^{a, b}$ \\
\hline Q50 & $334 \cdot 1 \pm 6 \cdot 7$ & $495 \cdot 7 \pm 25 \cdot 1^{\mathrm{a}}$ & $3 \cdot 21 \pm 0 \cdot 67^{b}$ & $284 \cdot 4 \pm 25 \cdot 3^{a}$ \\
\hline Q100 & $353 \cdot 9 \pm 5 \cdot 5$ & $509 \cdot 8 \pm 22 \cdot 3^{a}$ & $3 \cdot 28 \pm 0 \cdot 87^{b}$ & $210 \cdot 5 \pm 27 \cdot 4^{\mathrm{a}, \mathrm{b}}$ \\
\hline Q150 & $338 \cdot 7 \pm 7 \cdot 2$ & $474 \cdot 6 \pm 21 \cdot 4^{a}$ & $6 \cdot 23 \pm 1 \cdot 14^{c}$ & $166 \cdot 5 \pm 35 \cdot 1^{b}$ \\
\hline $\mathrm{F} 1$ & $343 \cdot 2 \pm 3 \cdot 7$ & $332 \cdot 4 \pm 19 \cdot 5^{b}$ & $5.65 \pm 0.92^{c}$ & $118 \cdot 4 \pm 24 \cdot 3^{c}$ \\
\hline F1Q50 & $343 \cdot 4 \pm 3 \cdot 2$ & $310 \cdot 3 \pm 18 \cdot 7^{\mathrm{b}, \mathrm{c}}$ & $3 \cdot 43 \pm 0 \cdot 72^{b}$ & $275 \cdot 2 \pm 39 \cdot 4^{a}$ \\
\hline F1Q100 & $348 \cdot 7 \pm 5 \cdot 6$ & $273 \cdot 2 \pm 17 \cdot 2^{c}$ & $5 \cdot 16 \pm 0 \cdot 49^{c}$ & $205 \cdot 9 \pm 34 \cdot 2^{a, b}$ \\
\hline F1Q150 & $336 \cdot 0 \pm 5 \cdot 8$ & $235 \cdot 5 \pm 14 \cdot 8^{c}$ & $4 \cdot 85 \pm 0.98^{\mathrm{c}}$ & $172 \cdot 1 \pm 23 \cdot 5^{b}$ \\
\hline
\end{tabular}

Numbers within columns with different superscript letters are significantly different from one another at $P<0.05$ (ANOVA).

\section{Immunohistochemistry and histology}

Fixed prostate, pancreas, liver, kidney and testis were routinely processed in a tissue processor and embedded in paraffin. Sections of $5 \mu \mathrm{m}$ were cut and subjected to immunohistochemical study using the ImmunoCruz Staining System (Lab Vision Corporation, Fremont, CA, USA). Briefly, the slides were deparaffinized, rehydrated gradually through graded alcohols, and incubated in 3\% $\mathrm{H}_{2} \mathrm{O}_{2}$ for 20 min to block endogenous peroxidase activity. The antigens were retrieved by boiling the slides in $10 \mathrm{mM}$ citrate buffer ( $\mathrm{pH} 6.0$ ) for $15 \mathrm{~min}$. After blocking unspecific background with 5\% skim milk for $20 \mathrm{~min}$ at room temperature, the slides were incubated with mouse anti-Ki-67 antibody overnight at $4{ }^{\circ} \mathrm{C}$. The slides were then incubated with the appropriate biotinylated secondary antibody, followed by peroxidase-conjugated streptavidin complex and diaminobenzidene. The sections were finally counterstained with hematoxylin. The slides were examined under an Olympus Provis microscope (BX60, Olympus Optical Corp., Toyota, Japan) and images were captured digitally with the Olympus DP11 camera (Olympus Optical Corp.). The Ki-67 labeling index was expressed as the percentage of clearly labeled Ki-67 reactive nuclei in total epithelial cells in randomly selected fields at a magnification of $\times 200(n=6)$.

\section{Quantitation of apoptosis}

Sections of $5 \mu \mathrm{m}$ were used to quantitate apoptosis in prostate tissues. Fragmented DNA was labeled using the ApoAlert DNA fragmentation assay (Clontech Laboratories, Palo Alto, CA, USA) which is based on the terminal deoxynucleotidyl transferase-mediated dUTP nick end labeling (TUNEL) as described (Nickerson et al. 1998). Labeling indices were obtained by counting the number of labeled cells among at least 100 epithelial cells per region and were expressed as percentage values.

\section{Serum androgen measurement}

Serum testosterone and DHT levels were determined using their respective enzyme-linked immunosorbent assay (ELISA) kits (IBL Immuno-Biological Laboratories, Hamburg, Germany) as described by the manufacturer. Briefly, an unknown amount of antigen present in the sample and a fixed amount of enzyme-labeled antigen competed for the binding sites of the antibodies coated onto the wells. After incubation, the wells were washed to stop the competition reaction and the tetramethylbenzidine (TMB) substrate solution was added. The measured optical density of the standards was used to construct a calibration curve against which the concentrations of the unknown samples were calculated. The concentration of antigen present in the samples was inversely proportional to the optical density measured at a wavelength of $450 \mathrm{~nm}$.

Determination of the concentration of total quercetin metabolites in serum

After ingestion of quercetin, the major circulating metabolites in rat blood are glucurono-sulfo conjugates of isorhamnetin and of quercetin (Morand et al. 1998). Quercetin, quercetin glycosides, quercetin glucuronides and quercetin sulfates were hydrolyzed to their aglycones by incubating $180 \mu \mathrm{l}$ rat serum, acidified to $\mathrm{pH} 4.9$ with $20 \mu \mathrm{l} 0.58 \mathrm{M}$ acetic acid solution, for $30 \mathrm{~min}$ at $37^{\circ} \mathrm{C}$ in the presence of $10 \mu \mathrm{l}$ enzyme mixture $\left(5 \times 10^{6} \mathrm{U} / 1\right.$ $\beta$-glucuronidase and $2.5 \times 10^{5} \mathrm{U} / 1$ sulfatase). The aglycones were then extracted with $500 \mu \mathrm{l}$ methanol/ $\mathrm{HCl}$ $(200 \mathrm{mM})$ followed by centrifugation (14000 $\mathrm{g}$ for $10 \mathrm{~min}$ ) (Morand et al. 2000). The concentrations of aglycones were determined by a reversed-phase high performance liquid chromatography (RP-HPLC) method in a chromatograph (Waters 2695 Separation Module, Milford, MA, USA) equipped with a Photodiode Array 


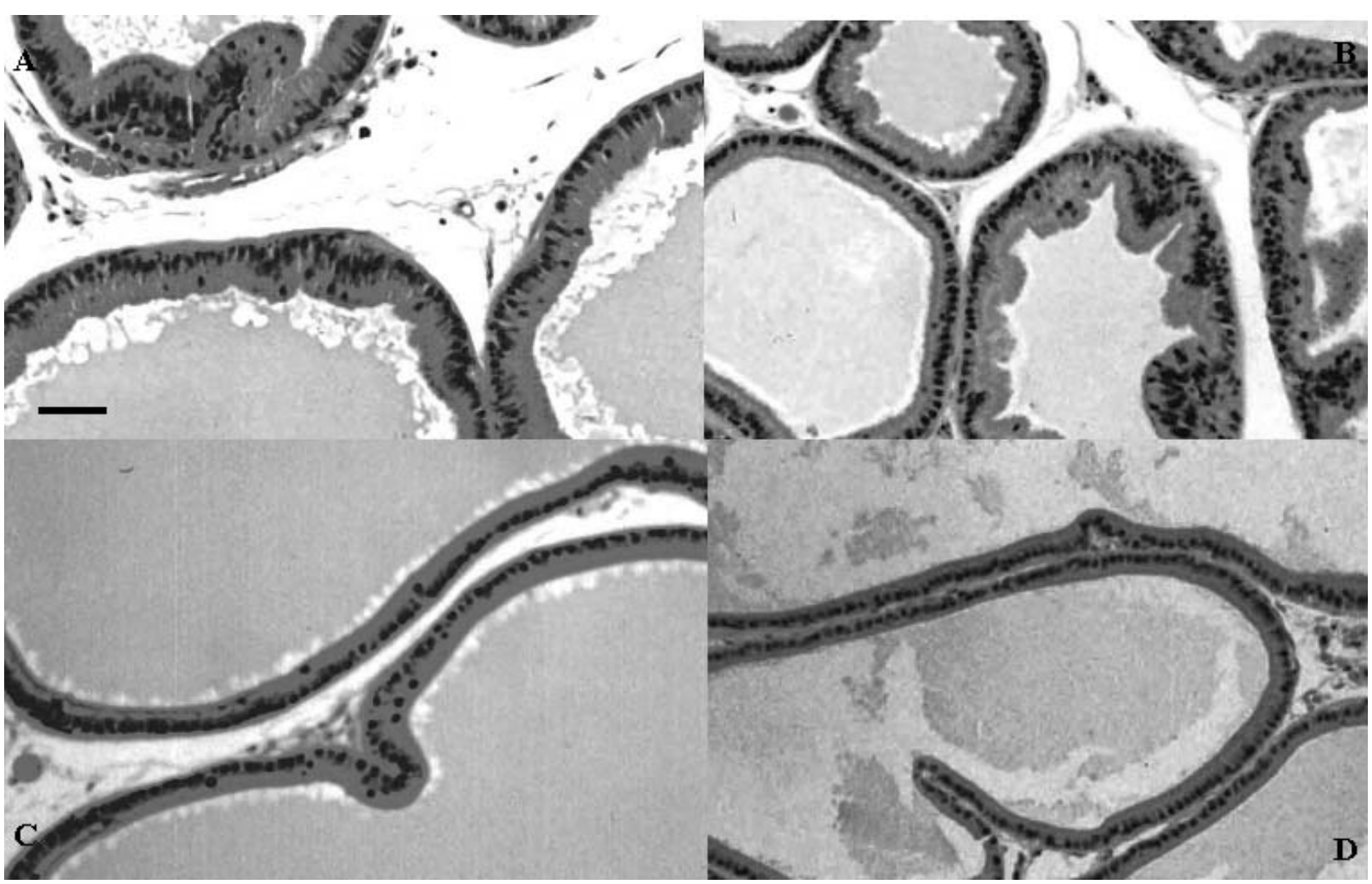

Figure 1 Effects of quercetin, finasteride and finasteride plus quercetin on prostate gland morphology. Rats were treated for 10 days with (A) vehicle, (B) finasteride (1 mg/kg body weight daily), (C) quercetin (150 mg/kg body weight daily), or (D) finasteride plus quercetin. Hematoxylin-eosin stain was used; scale bar $=10 \mu \mathrm{m}$.

detector (Waters 2996) and a Waters Symmetry column $\left(\mathrm{C}_{18}, 5 \mu \mathrm{m}, 3.9 \times 150 \mathrm{~mm}\right)$. The mobile phase consisted of $60 \%$ methanol and $40 \%$ phosphoric acid solution (0.5\%). The injection volume, the flow rate and the detection wavelength were $20 \mu \mathrm{l}, 0.7 \mathrm{ml} / \mathrm{min}$ and $370 \mathrm{~nm}$ respectively. The total quercetin metabolites in serum were determined by summing the concentrations of the aglycones, i.e. isorhamnetin, quercetin and tamarixetin, which were determined against their respective standard curves.

\section{Western blot analysis}

To determine the changes in the expression levels of cell cycle-regulated proteins, the frozen rat prostate was homogenized in lysis buffer $(1 \mathrm{mM} \mathrm{CaCl}, 1 \mathrm{mM} \mathrm{MgCl} 2,1 \%$ $\mathrm{NP}-40,1 \mu \mathrm{g} / \mathrm{ml}$ leupeptin, $1 \mu \mathrm{g} / \mathrm{ml}$ aprotinin, $1 \mu \mathrm{M}$ phenylmethylsulfonyl fluoride, and $100 \mu \mathrm{M} \mathrm{NaVO}$ ). One hundred micrograms proteins were subjected to Western blot analysis as described (Huynh et al. 1995). Blots were incubated with the indicated primary antibodies followed by horseradish peroxidase-conjugated donkey antimouse or antirabbit secondary antibody $(1: 7500)$. Blots were visualized with a chemiluminescent detection system (Amersham Pharmacia Biotech UK Ltd, UK) as described by the manufacturer. For quantitative analysis, the density of bands corresponding to the protein blotting with the antibodies under study was calculated with the Quality One software (Bio-Rad Laboratories, Hercules, CA, USA) and was normalized to that of $\alpha$-tubulin.

\section{Statistical analysis}

Comparison between the different groups was performed by one-way ANOVA (SPSS 10, SPSS Inc. Chicago, IL, USA) with the Student's unpaired $t$-test applied for paired comparisons of means. $P$ values of 0.05 or less were considered significant, while values of $0 \cdot 01$ or less were considered very significant.

\section{Results}

Effects of finasteride and quercetin on the rat body weight and wet prostate weight

Treatment of rats with 50, 100 or $150 \mathrm{mg}$ quercetin/ $\mathrm{kg}$ for 10 days resulted in an insignificant increase in wet prostate weight regardless of the doses used (Table 1). Finasteride 
at a dose of $1 \mathrm{mg} / \mathrm{kg}$ body weight caused a significant $26.9 \%$ reduction in wet prostate weight as compared with controls $(P<0 \cdot 001)$ (Table 1). Co-administration of finasteride with 50,100 and $150 \mathrm{mg}$ quercetin $/ \mathrm{kg} \mathrm{BW}$ decreased the wet prostate weight by $31 \cdot 8 \%, 40 \cdot 0 \%$ and $48.2 \%$ respectively. There was a linear relationship between the wet prostate weight and the quercetin dose in the co-treated groups $\left(\mathrm{R}^{2}=0.991\right)$, with the most significant effect being observed when finasteride was administered together with $150 \mathrm{mg}$ quercetin $(P<0 \cdot 001)$. There was, however, no statistically significant change in the body weight of rats.

Effects of finasteride and quercetin on the histology of rat prostate, pancreas, liver, kidney and testis

As shown in Fig. 1A, the alveoli of control prostates were lined with a layer of tall columnar epithelial cells with a high cytoplasm/nuclear ratio. The luminal epithelial cells showed a marked reduction in cytoplasm and their secretory activity became diminished after finasteride treatment for 10 days (Fig. 1B). Compared with the control prostate gland, the lumens of prostate glands derived from finasteride-treated rats were markedly reduced in size (Fig. 1B compared with Fig. 1A). Quercetin treatment, on the other hand, caused a dramatic dilation of the prostate lumen. The lumens were filled with secretory materials (Fig. 1C), indicating that quercetin enhanced the secretory activity of epithelial cells. The increase in luminal volume was accounted for by a significant $(P<0 \cdot 01)$ decrease in the average cell number per unit area, reaching $63 \%$ of control rats (Table 2). Co-administration of finasteride and quercetin, however, led to additive effects on the thickness of the prostate epithelium. The cytoplasm was greatly reduced and the epithelial layer became very thin (Fig. 1D). No marked change in the cell morphology or histology was observed in the slides of pancreas, liver, kidney and testis (data not shown).

\section{Effects of finasteride and quercetin on serum androgen levels}

Quercetin and finasteride, when administered as a single agent for 10 days, significantly increased serum testosterone levels $(P<0 \cdot 001)$ after 10 days of treatment (Table 1$)$. As expected, finasteride significantly decreased serum DHT levels to half that of the control rats (118 vs $228 \mathrm{pg} / \mathrm{ml}, \quad P<0 \cdot 01$ ) (Table 1). Quercetin treatment, however, resulted in a biphasic change in serum DHT concentration, which was slightly increased at a dose of $50 \mathrm{mg} / \mathrm{kg} \mathrm{BW}$, but decreased at a dose of $150 \mathrm{mg} / \mathrm{kg} \mathrm{BW}$. Similar effects were seen when quercetin was given together with finasteride. It was noteworthy that the intake of quercetin dampened the effects of finasteride on the levels of both serum testosterone and DHT. Compared

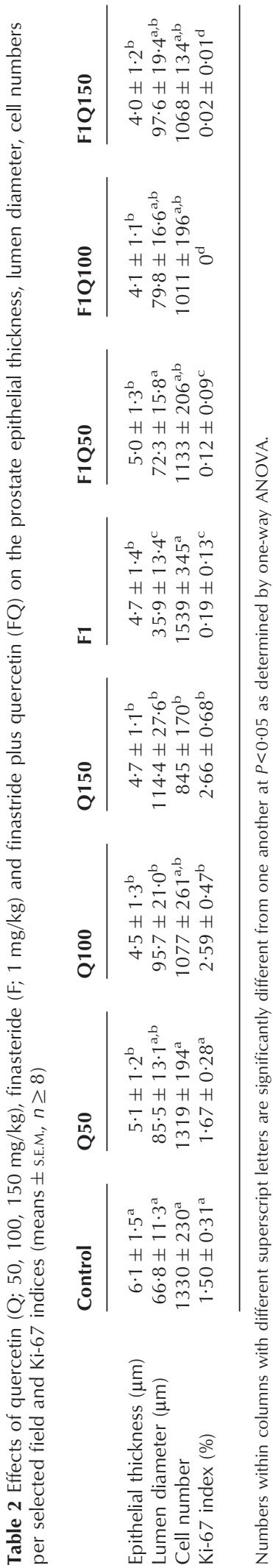

Journal of Endocrinology (2004) 181, 493-507 


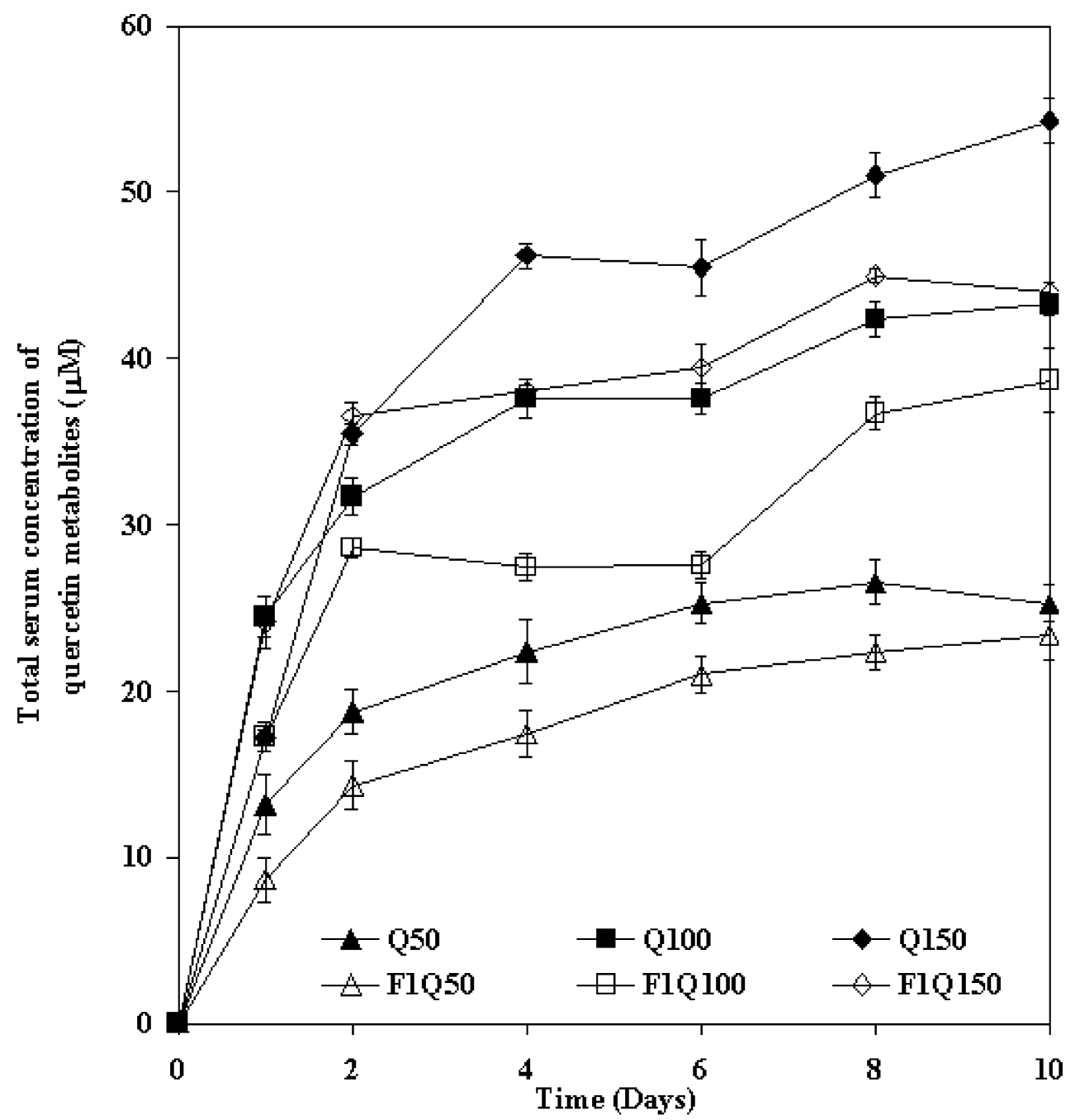

Figure 2 Total serum concentrations of quercetin metabolites $4 \mathrm{~h}$ after ingestion of quercetin in the presence or absence of finasteride (mean \pm S.E.M., $n=8$ ). Rats were treated as described in Table 1 . The concentrations of quercetin metabolites at a given time were determined by the RP-HPLC method as described in Materials and Methods and were plotted against time. Q, quercetin; F, finasteride.

with finasteride alone, the combined treatment increased serum DHT levels by $2 \cdot 32-, 1 \cdot 74-$ and $1 \cdot 45$-fold at doses of 50,100 and $150 \mathrm{mg}$ quercetin/ $\mathrm{kg} \mathrm{BW}$ respectively.

\section{Concentration of quercetin metabolites in serum}

To determine the total serum concentrations of quercetin and its metabolites, serum-derived from quercetin-treated rats was treated with $\beta$-glucuronidase and sulfatase which reduced quercetin metabolites to their aglycones i.e. isorhamnetin, quercetin and tamarixetin. The levels of these aglycones were measured by the RP-HPLC method. As shown in Fig. 2, a dose-dependent elevation in serum quercetin metabolites was observed. The levels of serum quercetin metabolites reached a plateau on the sixth day. The serum concentration of quercetin metabolites was $25.3 \mu \mathrm{M}, 43.3 \mu \mathrm{M}$ and $54.3 \mu \mathrm{M}$ after 10 days of treatment with $50 \mathrm{mg}, 100 \mathrm{mg}$ and $150 \mathrm{mg}$ quercetin $/ \mathrm{kg}$ BW respectively. Co-administration of quercetin with finasteride caused a significant decline in serum quercetin metabolite concentrations $(P<0 \cdot 01)$ (Fig. 2). This effect was observed for all the three tested quercetin regimens.

\section{Effects of quercetin and finasteride on prostate apoptosis and proliferation}

The TUNEL assay and Ki-67 indices were performed on prostate sections to determine whether the apoptosis or cell cycle arrest of prostate epithelial cells contributed to the reduction in wet prostate weight caused by combined 


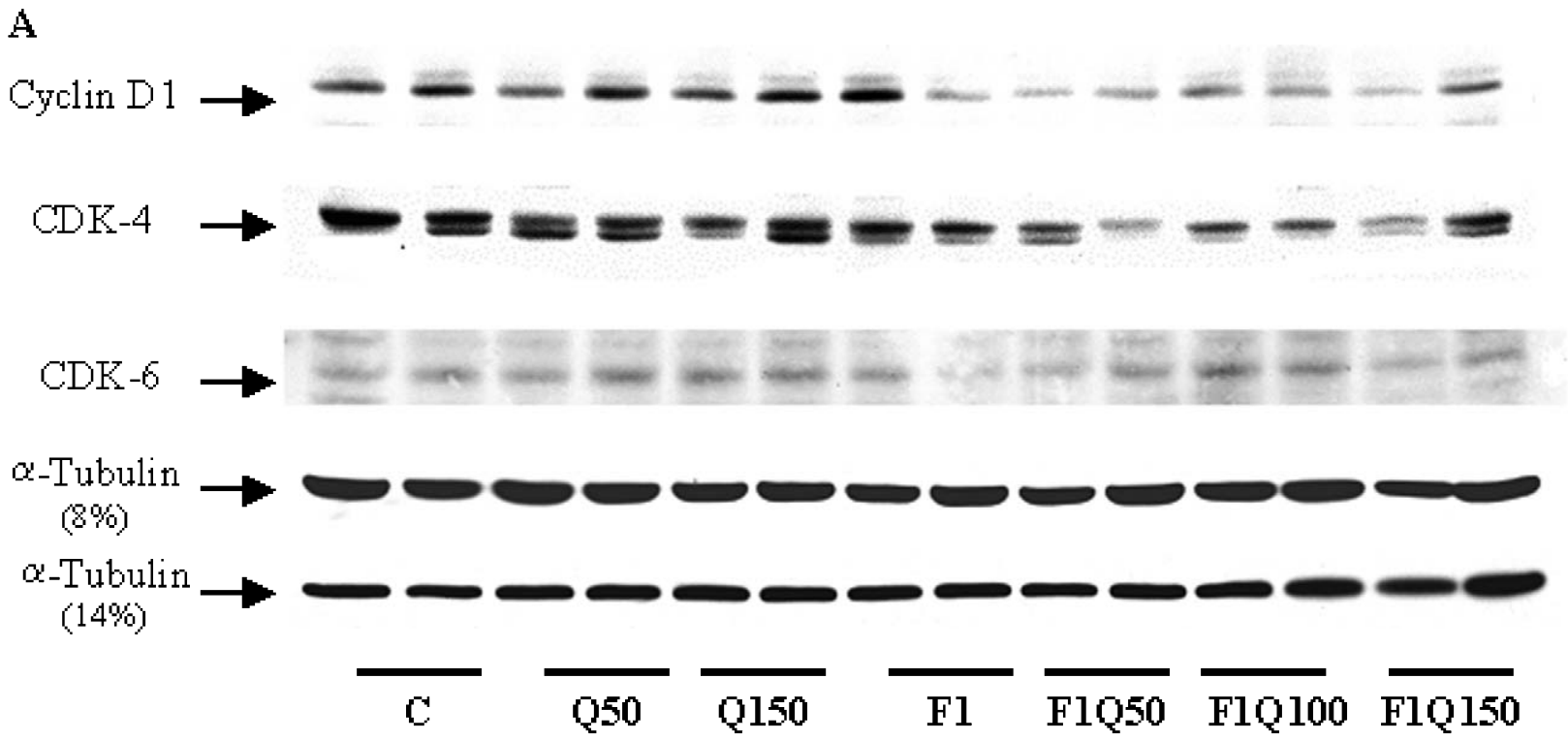

B

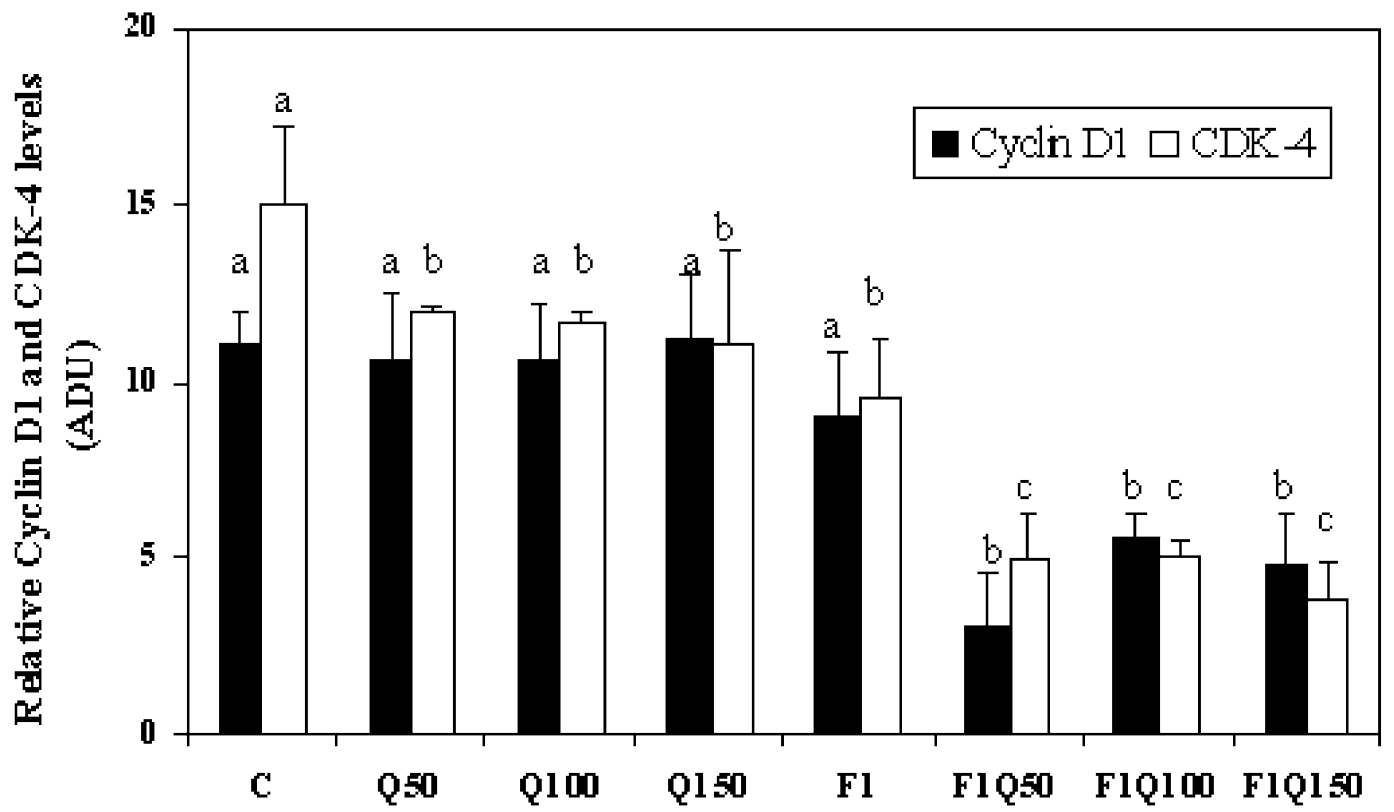

Figure 3 Effects of quercetin $(Q)$, finasteride $(F)$ and finasteride plus quercetin (FQ) on the expression of cyclin D1 and CDK4/CDK-6 in the prostate gland. Treatments were the same as those described in Table 1. Tissue lysates (100 $\mu$ g protein/lane) were subject to Western blot analysis as described in Materials and Methods. Blots were incubated with mouse anti-cyclin D1, rabbit anti-CDK-4, mouse anti-CDK-6 and mouse anti- $\alpha$-tubulin antibodies. Representative blots are shown in (A). Densitometric scanning of the cyclin D1 and CDK-4 bands after being normalized to the levels of $\alpha$-tubulin is shown in (B). Data are expressed as the mean of 8 samples \pm S.E.M. Bars with different letters are significantly different from one another at $P<0.05$ as determined by one-way ANOVA. ADU, arbitrary densitometric units. (C), control.

quercetin-finasteride treatment. Apoptosis was increased from $0 \cdot 3 \pm 0 \cdot 2 \%$ in the control group to $1 \cdot 1 \pm 0 \cdot 7 \%$ in finasteride-treated groups. The apoptotic rate in quercetin-finasteride treatments was $1 \cdot 3 \pm 0 \cdot 8 \%$. The results indicated no significant changes in apoptosis between finasteride and quercetin-finasteride treatments. The Ki-67 index of prostate epithelial cells in the control group was $1.5 \%$ and that was significantly decreased by 
A

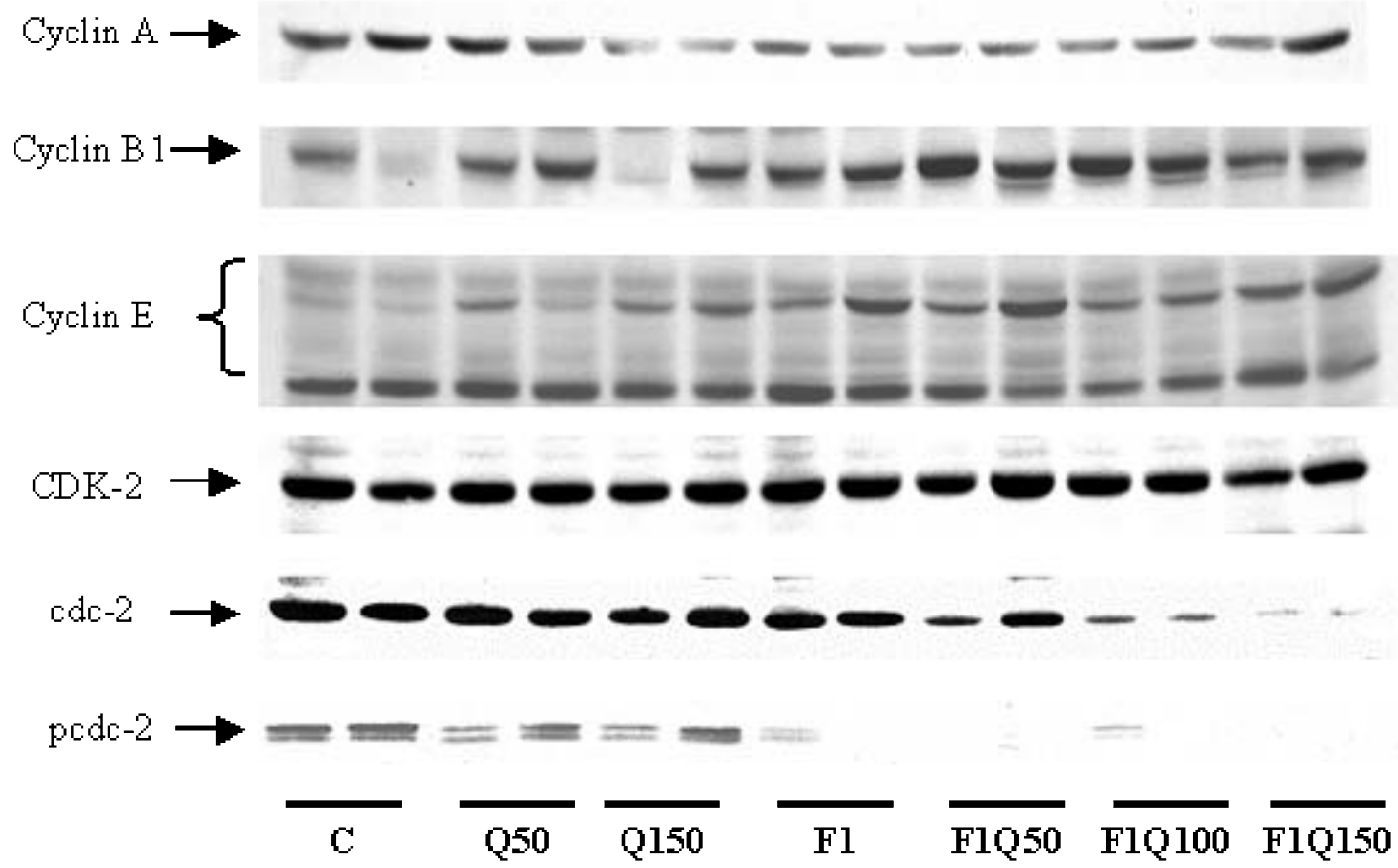

B

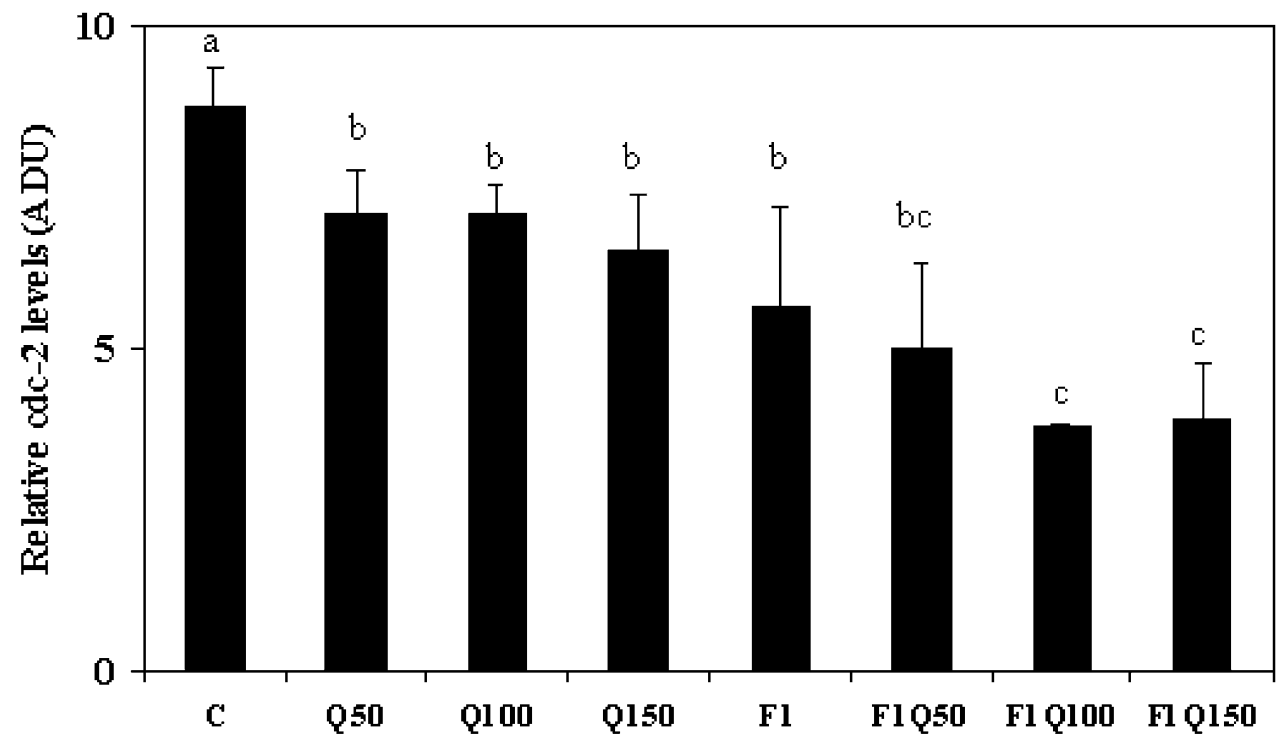

Figure 4 Effects of quercetin $(Q)$, finasteride $(F)$ and finasteride plus quercetin $(F Q)$ on the expression of cyclin $A$, cyclin B1, cyclin E, CDK-2 and cdc-2 in the prostate gland. Rats were treated as described in Table 1. Tissue lysates (100 $\mu \mathrm{g}$ protein/lane) were subject to Western blot analysis as described in Materials and Methods. Blots were incubated with rabbit anti-cyclin A, rabbit anti-cyclin B1, mouse anti-cyclin E, mouse anti-CDK-2, rabbit anti-cdc-2 and rabbit anti-phosphorylated (p) cdc-2 (Tyr15) antibodies. Representative blots are shown in (A). Densitometric scanning of the cyclin cdc-2 bands after being normalized to the levels of $\alpha$-tubulin is shown in (B). Data are expressed as the mean of 8 samples \pm S.E.M. Bars with different letters are significantly different from one another at $P<0.05$ as determined by one-way ANOVA. ADU, arbitrary densitometric units. (C), control. 
finasteride or combined treatments $(P<0 \cdot 05)$ (Table 2). On the other hand, quercetin significantly increased the $\mathrm{Ki}-67$ index at doses of 100 and $150 \mathrm{mg} / \mathrm{kg} \mathrm{BW}$.

\section{Effects of quercetin and finasteride on cyclin D/CDK-4/6}

The major rate limiting step in the mammalian cell cycle is the transition of G1 to S phase, which is initiated by the activation of cyclin $\mathrm{D}$ and its association to $\mathrm{CDK}-4$ and CDK-6 (Coqueret 2002); therefore the in vivo effects of quercetin and finasteride on cyclin D1 and CDK-4/6 were examined. As shown in Fig. 3, quercetin alone had no effect on the levels of cyclin D1. Finasteride, at a dose of $1 \mathrm{mg} / \mathrm{kg} \mathrm{BW}$, reduced the cyclin D1 and CDK-4 levels by $19 \%$ and $27 \%$ respectively. Co-administration of quercetin and finasteride resulted in an approximately $50 \%$ to $70 \%$ reduction in the expression of cyclin D1 and CDK-4 respectively $(P<0 \cdot 05)$. Quercetin and finasteride when given alone or in combination did not alter the expression of CDK-6.

\section{Effects of quercetin and finasteride on other cyclins and CDKs}

In order for the cells to enter into the $\mathrm{S}$ phase of the cell cycle, activation of cyclin $\mathrm{E}$ is required. Activated cyclin $\mathrm{E}$ binds to and activates CDK-2 (Sherr 1996). Cyclins A and $\mathrm{B}$ are then combined with $\mathrm{CDK}-2$ and cdc-2 to induce cell cycle progression. Because cyclin $\mathrm{E}$ is required for CDK-2 activation and cyclins A and B are required for cell cycle progression through $S$ and into $M$ phase (Sherr 1996), the levels of cyclin A, cyclin B1, cyclin E, CDK-2, $\mathrm{cdc}-2$ and phosphorylated (p) cdc-2 were determined. As shown in Fig. 4, cyclin E appeared as two bands at approximately $50 \mathrm{kDa}$ and $42 \mathrm{kDa}$. Quercetin or finasteride alone caused a slight increase in the $50 \mathrm{kDa}$ band without significantly affecting the total cyclin $\mathrm{E}$ levels. Co-administration of quercetin and finasteride resulted in a decrease in the $42 \mathrm{kDa}$ band while elevating the $50 \mathrm{kDa}$ band. Cyclin A expression was downregulated to $23 \cdot 4 \%$ and $40.5 \%$ of the control by finasteride and the $150 \mathrm{mg} / \mathrm{kg}$ dose of quercetin respectively. No further decrease in cyclin A levels was observed when quercetin and finasteride were given together. The levels of CDK-2, the common catalytic partner of cyclin E and cyclin A, did not differ among all treatment groups. For the cdc-2 kinasecyclin B complex, while the cyclin B1 levels were increased by $1 \cdot 8$-fold, the cdc- 2 expression was decreased by approximately $50 \%$ by finasteride as compared with controls (Fig. 4). Quercetin alone produced only a moderate effect on cdc-2 expression. Finasteride and quercetin acted synergistically to reduce both cdc-2 and its phosphorylation at tyrosine 15 .

\section{Effects of quercetin and finasteride on cyclin-dependent kinase inhibitors (CKIs)}

Because the activity of CDKs can be negatively regulated by CKIs (Vidal \& Koff 2000, Lee \& Yang 2001), the effects of quercetin, finasteride and their combination on the levels of p15, p16, p21 and p27 were investigated. As shown in Fig. 5, although the expression of p15 was significantly down-regulated by finasteride and quercetin alone, the levels of p15 were significantly elevated when finasteride was given together with the two higher doses of quercetin (100 and $150 \mathrm{mg} / \mathrm{kg} \mathrm{BW})(P<0 \cdot 05)$. In contrast, quercetin alone caused a significant increase in p21 levels $(P<0 \cdot 05)$. Although finasteride alone made no contribution to the expression of $\mathrm{p} 21$, co-administration of quercetin with finasteride caused a significant increase in the level of p21 $(P<0 \cdot 05)$. Similarly, the combined treatment also augmented the expression of p27. No difference in the expression of p16 was observed (data not shown).

Effects of quercetin and finasteride on $p R b$ and its phosphorylation

It has been reported that $\mathrm{pRb}$ negatively regulates the cellular G1/S transition of the proliferative cell cycle (Adams 2001) and cyclin D1/CDK-4 preferentially phosphorylates $\mathrm{pRb}$ at serine 780 (Kitagawa et al. 1996) and serine 795 (Pan et al. 1998, Grafstrom et al. 1999). The abundance of hypophosphorylated $\mathrm{pRb}$ and its phosphorylation on serine 780 , serine 795 and serine $807 / 811$ in quercetin-, finasteride- and quercetin-finasteridetreated prostates was examined using $\mathrm{pRb}$ and phosphospecific antibodies. As shown in Fig. 6, both quercetin and finasteride and finasteride-quercetin caused a slight increase in total $\mathrm{pRb}$. When the blots were stripped and re-blotted with anti-phospho $\mathrm{pRb}$ (Ser780), anti-phospho $\mathrm{pRb}$ (Ser795) or anti-phospho pRb (Ser807/811), a significant increase in phosphorylated $\mathrm{pRb}$ at serine 780 and serine $807 / 811$ was observed in quercetin- or finasteride-treated samples $(P<0 \cdot 01)$. Co-treatment of finasteride with quercetin, on the other hand, caused a significant reduction in $\mathrm{pRb}$ phosphorylation at serine 780 and serine $807 / 811$. Phosphorylation of $\mathrm{pRb}$ at serine 795 was not affected by any of the treatments (data not shown). The relative ratio of total $\mathrm{pRb}$ phosphorylation to the total $\mathrm{pRb}$ hypophosphorylation was significantly higher in quercetin- and finasteride-treated groups. This ratio was reversed when quercetin was co-administered with finasteride (Fig. 6).

Effects of quercetin and finasteride on the MAPK and PI-3 kinase pathways

It has been demonstrated that growth factors and steroid hormones promote cell cycle progression via the MAP kinase and PI-3 kinase pathways, both of which contribute to the expression and stability of cyclin D1 (Roovers \& Assoian 2000, Coqueret 2002) which is known to target $\mathrm{pRb}$. It was reasonable to suppose that downregulation of cyclin D1 following quercetin/finasteride combined 

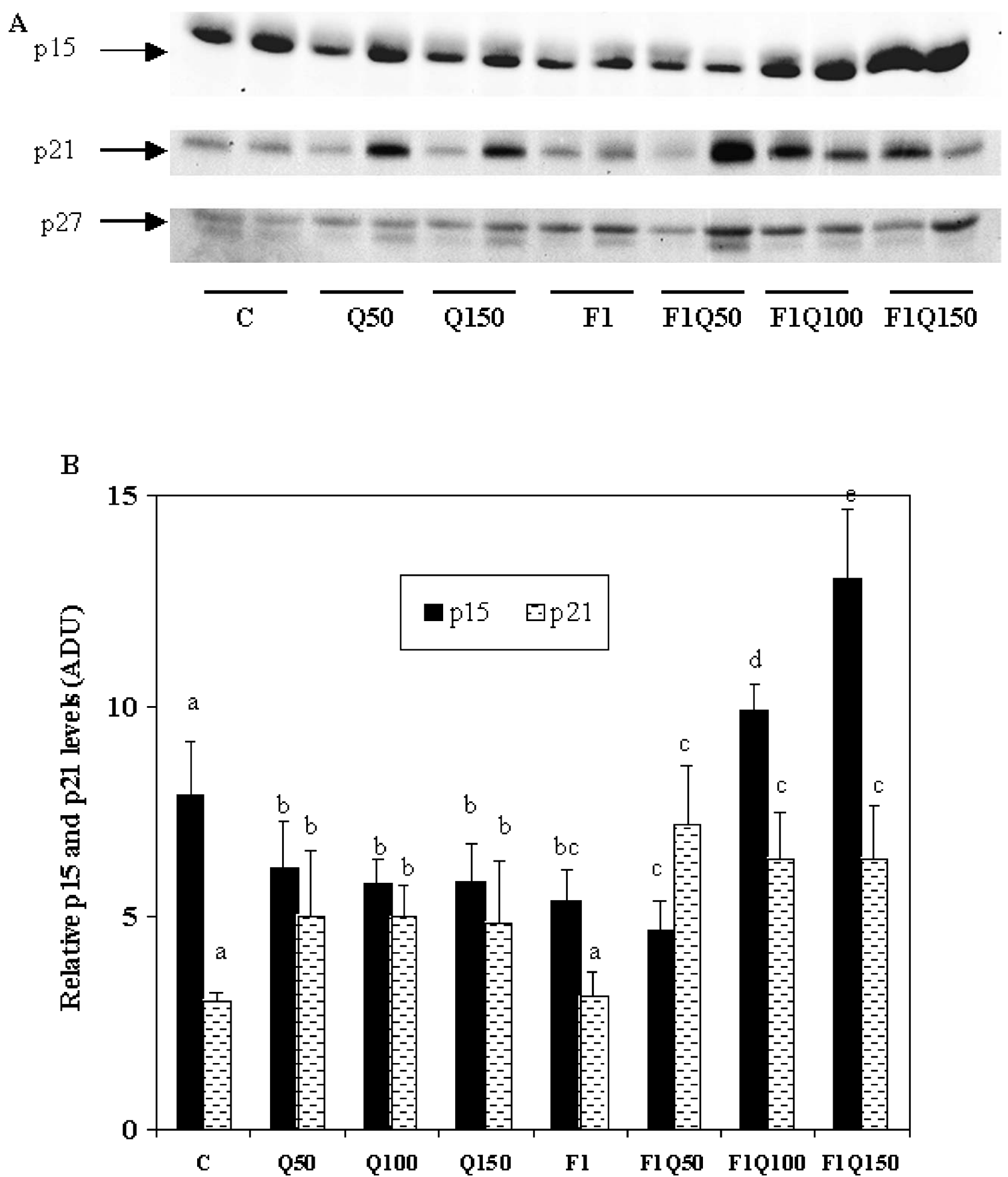

Figure 5 Effects of quercetin $(Q)$, finasteride $(F)$ and finasteride plus quercetin (FQ) on the expression of p15, p21 and p27 in the prostate gland. Rats were treated as described in Table 1 . Tissue lysates (100 $\mu$ g protein/lane) were subject to Western blot analysis as described in Materials and Methods. Blots were incubated with mouse anti-p15, mouse anti-p21 and mouse anti-p27 antibodies. Representative blots are shown in (A). Densitometric scanning of p15 and p21 bands after being normalized to the levels of $\alpha$-tubulin is shown in (B). Data are expressed as the mean of 8 samples \pm S.E.M. Bars with different letters are significantly different from one another at $P<0 \cdot 05$ as determined by one-way ANOVA. ADU, arbitrary densitometric units. (C), control. 
A

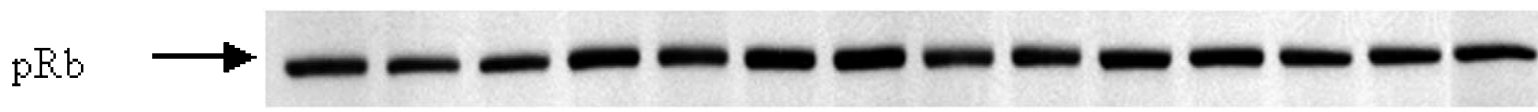

Phospho-pRb (Ser780)
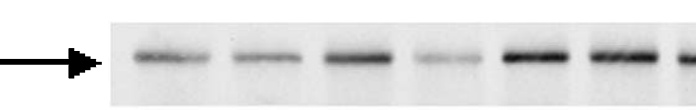

Phospho-pRb
$($ Ser807/811)
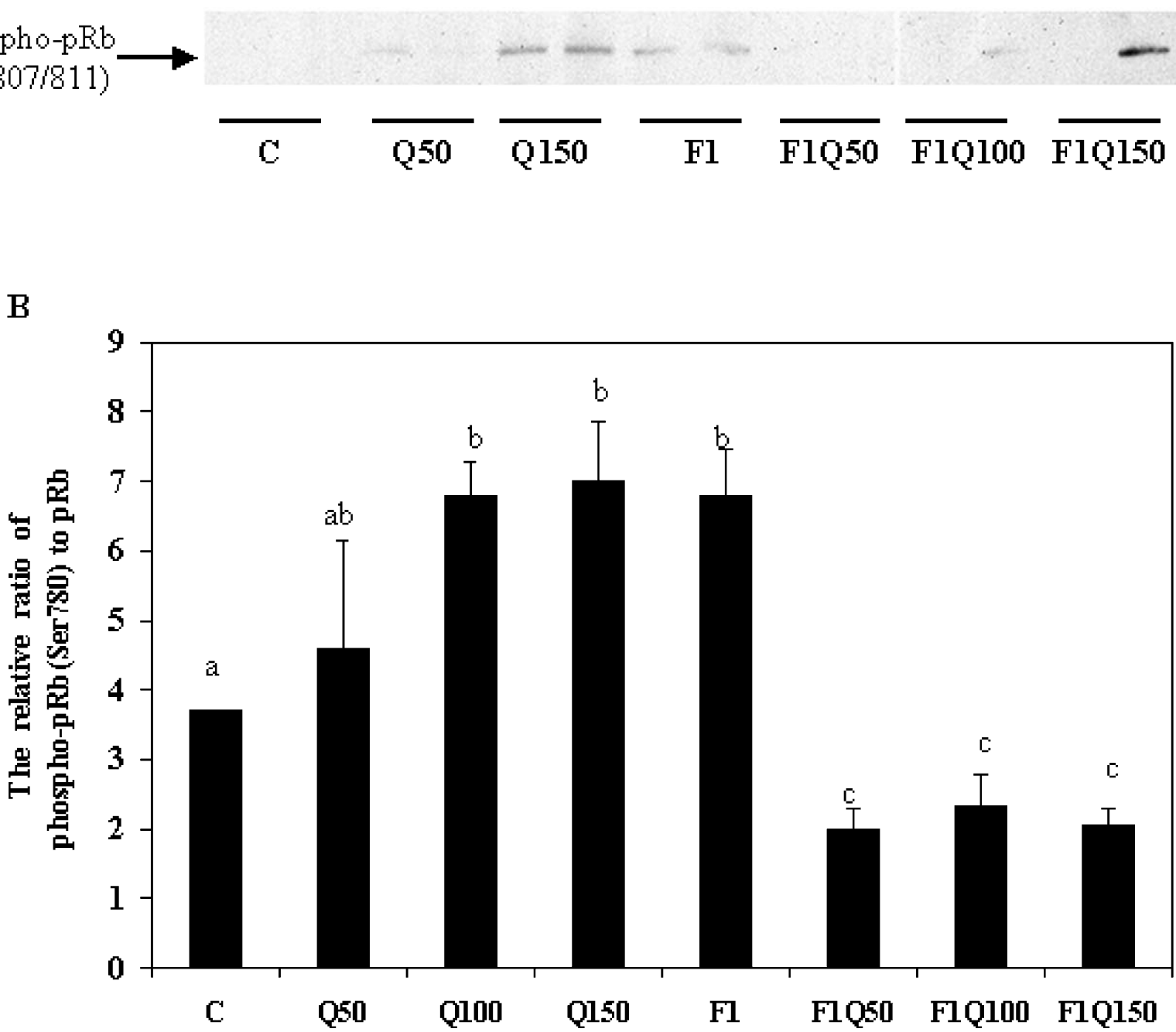

Figure 6 Effects of quercetin $(\mathrm{Q})$, finasteride $(\mathrm{F})$ and finasteride plus quercetin $(\mathrm{FQ})$ on the expression of pRb and phosphorylated pRb in the prostate gland. Rats were treated as described in Table 1 . Tissue lysates (100 $\mu$ g protein/lane) were subject to Western blot analysis as described in Materials and Methods. Blots were incubated with mouse anti-pRb, rabbit anti-phosphorylated pRb (Ser780) and rabbit anti-phosphorylated pRb (Ser807/811) antibodies. Representative blots are shown in (A). The relative ratio (in arbitrary densitometric units) of the densitometric scanning of hyperphosphorylated $\mathrm{pRb}$ (Ser780) bands to $\mathrm{pRb}$ bands after being normalized to the levels of $\alpha$-tubulin is shown in (B). Data are expressed as the mean of 8 samples \pm S.E.M. Bars with different letters are significantly different from one another at $P<0.05$ as determined by one-way ANOVA. (C), control.

treatment might be due to inhibition of MAPK or PI-3 kinase or both. As shown in Fig. 7, quercetin or finasteride alone had a minimal effect on activation of MAPK and p85 subunit of PI-3 kinase as determined by the levels of phosphorylated MAPK and phosphorylated Akt-1 respectively. Co-treatment of quercetin and finasteride led to a significant decrease in phosphorylated MEK1/2, phosphorylated MAPK but not phosphorylated Akt-1, suggesting that quercetin/finasteride preferentially inhibits the activation of MAPK but not PI-3 kinase. The p44 MAPK 


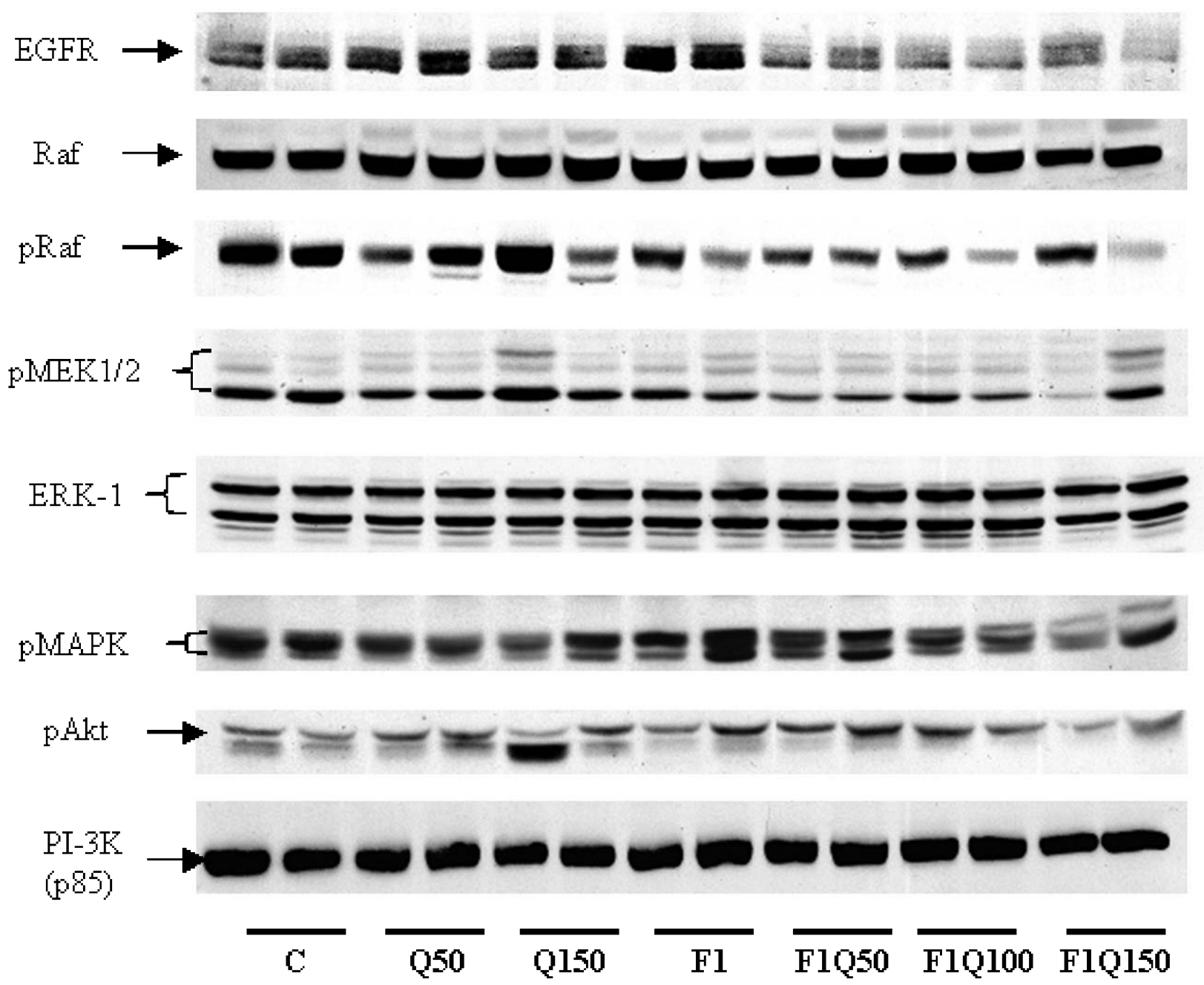

Figure 7 Effects of quercetin $(\mathrm{Q})$, finasteride $(\mathrm{F})$ and finasteride plus quercetin (FQ) on the expression of EGFR, Raf, pRaf, pMEK1/2, ERK-1, pMAPK, pAkt and PI-3 kinase (PI-3K) in the prostate gland. Rats were treated as described in Table 1. Tissue lysates (100 $\mu \mathrm{g}$ protein/lane) were subject to Western blot analysis as described in Materials and Methods. Blots were incubated with rabbit anti-EGFR, rabbit anti-Raf, rabbit anti-pRaf, rabbit anti-phospho MEK1/2 (Ser217/221), mouse anti-ERK-1, mouse anti-phospho p44/42 MAP kinase (Thr202/Tyr204), rabbit anti-phospho-Akt-1 (Ser473) and rabbit anti-p85 subunit of Pl-3 kinase antibodies. Representative blots are shown. (C), control.

band showed a gradually faster mobility with an increase in quercetin dose together with finasteride. The upstream proteins of MAPK, e.g. EGFR and pRaf, were also significantly downregulated by the combined treatments (Fig. 7).

\section{Discussion}

Epidemiological studies have suggested an association between the low risk of hormone-dependent cancers including prostate cancer and the intake of some phytochemicals, a rich source of which are fruits and vegetables (Denis et al. 1999). These phytochemicals, depending on their concentrations, showed a mixed agonist/antagonist activity on steroid hormone systems. Quercetin, genistein and resveratrol (Lu \& Serrero 1999, Maggiolini et al. 2001) could act as an agonist at doses below $1 \mu \mathrm{M}$, and as an antagonist at higher doses in MCF-7 cells. This was also the case for quercetin and genistein in LNCaP cells (Denis et al. 1999). Furthermore, the cell cycle effect of quercetin was shown to be dose dependent (Choi et al. 2001, Kaneuchi et al. 2003). Most of the previous studies were focused on the in vitro effects of quercetin using cell lines. The in vivo effects of this compound remained unknown. Because absorption efficiency and rate of clearance of quercetin in vivo was far more complicated than in the in vitro cell culture experiments, we conducted these experiments to examine the in vivo effects of quercetin 
alone or in combination with finasteride on wet prostate weight.

The AR-dependent and -independent effects of phytoestrogens such as quercetin, genistein (Denis et al. 1999, Maggiolini et al. 2001) and resveratrol (Lu \& Serrero 1999) on prostate cancer cell lines have been widely reported. In addition, resveratrol showed both a stimulatory and an inhibitory effect on the AR-positive LNCaP cell line, but only an inhibitory effect on the AR-negative DU145 prostate cancer cell line (Kuwajerwala et al. 2002). Compared with finasteride alone, the finasteridequercetin combined treatment increased serum DHT levels (Table 1). Despite the strong potency of DHT in the prostate, quercetin-finasteride treatments registered a dramatic decrease in wet prostate weight in a dosedependent manner. This implies that quercetin might synergize with finasteride to activate or block an androgen-independent pathway(s) to regulate the growth and activity of prostate epithelial cells.

In this study, we demonstrated that combined quercetin-finasteride treatments reduced the phosphorylation of Raf, MEK1/2 and MAPK. A wide variety of hormones, growth factors and differentiation factors employ the MAPK pathway. We tested the expression levels of various tyrosine receptor kinases and growth factor receptors and found that EGFR was significantly down-regulated by the combined treatments. The decrease in EGFR might account, at least in part, for the observed decreases in the expression of the phosphoMEK1/2 and phospho-MAPK pathways in the prostates treated with the quercetin-finasteride combination. It is widely accepted that mitogens promote cell cycle progression via the MAPK and PI-3 kinase pathways, both contributing to the expression and stability of cyclin D1 (Roovers \& Assoian 2000, Coqueret 2002). Therefore, it was possible that the reduction in MAPK activity resulted in the inhibition of cyclin D1 expression in the combined treatments. Down-regulation of cyclin D1 and its catalytic partner, CDK-4, would prevent the formation of cyclin D/CDK-4 complexes. In this way, the phosphorylation of retinoblastoma protein $(\mathrm{pRb})$ by the cyclin $\mathrm{D} / \mathrm{CDK}-4$ complex could be reduced allowing more hypophosphorylated $\mathrm{pRb}$ to bind $\mathrm{E} 2 \mathrm{~F}$ transcription factors and thereby negate E2F activity (Coqueret 2002, Yam et al. 2002). Inhibition of cdc- 2 expression by quercetin-finasteride treatment would prevent the formation of the cyclin $\mathrm{A} / \mathrm{cdc}-2 / \mathrm{CDK} 2$ or the cyclin $\mathrm{B} / \mathrm{cdc}-2 / \mathrm{CDK}-2$ complex, which play an important role in both $\mathrm{S}$ and $\mathrm{M}$ phase (Yam et al. 2002). The undetectable levels of phospho-cdc-2 at Tyr15 might be due to the low levels of cdc-2 in quercetin-finasteride treatment. Among all the cyclins and CDKs examined, only cyclin B1 was found to be up-regulated by the combined treatment. It was noteworthy that there was a minor band which migrated faster than the main cyclin B1 band. Although the status of this band remains to be determined, it could be the dephos- phorylated form of cyclin B1. It has been reported that phosphorylation of cyclin B1 on five sites was required for cyclin B1 to accumulate in the nucleus and to activate cyclin B-cdc-2 kinase (Peter et al. 2002). Furthermore, among the five phosphorylation sites, phosphorylation of Ser94 and Ser96 could not progress without the activity of MAPK (Walsh et al. 2003). Considering the electrophoretical mobility pattern of phospho-MAPK, whose mobility was significantly increased with the increased dose of quercetin in the combined treatments, we postulated that although the level of cyclin B1 was increased, it might not be activated due to the inhibition of MAPK activity by the combined treatments. The low molecular weight (LMW) forms of cyclin E, which are predominantly derived from proteolytic processing of the full length cyclin E $(50 \mathrm{kDa})$, are hyperactive and can stimulate the cell to progress through the cell cycle more effectively than does full-length cyclin E (Porter et al. 2001). The inhibition on the generation of LMW isoforms would negatively regulate the cellular G1/S transition in the combined groups.

The cell cycle progression was further inhibited by the up-regulation of CKI levels in the combined treatments. The induction of p21, p15 and p27 might be important mechanisms for $G_{0} / G 1$ and $G 2 / M$ arrest in mammalian cells. The p21 protein is able to bind cdc2-cyclin B1, cyclin A/CDK-2 and cyclin E/CDK-2 complexes and inhibit their activity ( $\mathrm{Lu}$ et al. 1999). The inhibitory function of p15 in cell cycle progression was to compete with D-type cyclins for binding to the CDK subunits (Vidal \& Koff 2000, Lee \& Yang 2001). In addition, phosphorylation of $\mathrm{pRb}$ at serine 780 was significantly reduced by quercetin-finasteride treatment. Hypophosphorylated $\mathrm{pRb}$ sequestered the transcriptional activity of the E2Fs (Adams 2001). Because cyclin D1/CDK-4 preferentially phosphorylates serine 780 (Kitagawa et al. 1996) and $\mathrm{p} 15$ modulates $\mathrm{pRb}$ phosphorylation (Stone et al. 1995), up-regulation of $\mathrm{p} 15$ or inhibition of cyclin D1 and CDK-4 expression following finasteride-quercetin treatment might, at least in part, be responsible for the inhibition of $\mathrm{pRb}$ phosphorylation at serine 780 .

In this study, we demonstrated that finasteridequercetin treatments down-regulated the expression of phospho-MEK1/2 and phospho-MAPK, and decreased the levels of cyclin D1, cdc-2, phosphorylated cdc-2, CDK-2 and CDK-4 and phosphorylated pRb. The combined treatments also led to up-regulation of p15, p21 and p27 and inhibition of $\mathrm{pRb}$ phosphorylation at serine 780 and serine $807 / 811$. The deregulation of cell cycleregulated proteins would change the physiological state of prostate epithelial cells and, therefore, alter the secretion activities of the prostate. In accordance with the phosphorylation levels of $\mathrm{pRb}$, quercetin increased the prostatic secretion activity while quercetin-finasteride treatments inhibited it. Consistent with the altered expression of cell cycle-regulated proteins, the epithelial cell layer of the 
prostate became thinner in the combined treatments and the cellular proliferation rate was also dramatically reduced. Thus, the reduction in wet prostate weight following quercetin-finasteride treatments was ascribed to the combination of their effects on epithelial secretion and cellular proliferation, both of which might result from cell cycle deregulation. The combined effects of quercetin and finasteride on cellular proliferation and cell cycle deregulation suggested that quercetin plus a low dose of finasteride may be useful in the treatment of $\mathrm{BPH}$ and prostate cancer. In this way, side effects of finasteride related to sexual dysfunction could be reduced or eliminated while its therapeutic goals were retained or even enhanced.

\section{Funding}

This work was supported by grants from A*STARBMRC (LS/00/017) to H H.

\section{References}

Adams PD 2001 Regulation of the retinoblastoma tumor suppressor protein by cyclin/cdks. Biochimica et Biophysica Acta 1471 M123-M133.

Agullo G, Gamet-Payrastre L, Manenti S, Viala C, Remesy C, Chap H \& Payrastre B 1997 Relationship between flavonoid structure and inhibition of phosphatidylinositol 3-kinase: a comparison with tyrosine kinase and protein kinase $\mathrm{C}$ inhibition. Biochemical Pharmacology 53 1649-1657.

Akita H, Hashimoto Y, Hibino M, Iizuka A \& Kohri K 2001 Critical role for cell cycle regulators in androgen receptor function. Hinyokika Kiyo 47 819-823.

Akiyama T, Ishida J, Nakagawa S, Ogawara H, Watanabe S, Itoh N, Shibuya M \& Fukami Y 1987 Genistein, a specific inhibitor of tyrosine-specific protein kinases. Journal of Biological Chemistry 262 $5592-5595$.

Ashida H, Fukuda I, Yamashita T \& Kanazawa K 2000 Flavones and flavonols at dietary levels inhibit a transformation of aryl hydrocarbon receptor induced by dioxin. FEBS Letters 476 213-217.

Bhatia N, Agarwal C \& Agarwal R 2001 Differential responses of skin cancer-chemopreventive agents silibinin, quercetin, and epigallocatechin 3-gallate on mitogenic signaling and cell cycle regulators in human epidermoid carcinoma A431 cells. Nutrition and Cancer 39 292-299.

Choi JA, Kim JY, Lee JY, Kang CM, Kwon HJ, Yoo YD, Kim TW, Lee YS \& Lee SJ 2001 Induction of cell cycle arrest and apoptosis in human breast cancer cells by quercetin. International Journal of Oncology 19 837-844.

Constantinou A \& Huberman E 1995 Genistein as an inducer of tumor cell differentiation: possible mechanisms of action. Experimental Biology and Medicine 208 109-115.

Coqueret O 2002 Linking cyclins to transcriptional control. Gene 299 $35-55$.

Cunha GR, Donjacour AA, Cooke PS, Mee S, Bigsby RM, Higgins SJ \& Sugimura Y 1987 The endocrinology and developmental biology of the prostate. Endocrinology Reviews 8 338-362.

Denis L, Morton MS \& Griffiths K 1999 Diet and its preventive role in prostatic disease. European Urology 35 377-387.
Feigl P, Blumenstein B, Thompson I, Crowley J, Wolf M, Kramer BS, Coltman CA Jr, Brawley OW \& Ford LG 1995 Design of the Prostate Cancer Prevention Trial. (PCPT). Controlled Clinical Trials 16 150-163.

Ferguson J, Zincke H, Ellison E, Bergstralh E \& Bostwick DG 1994 Decrease of prostatic intraepithelial neoplasia following androgen deprivation therapy in patients with stage $\mathrm{T} 3$ carcinoma treated by radical prostatectomy. Urology 44 91-95.

Grafstrom RH, Pan W \& Hoess RH 1999 Defining the substrate specificity of cdk4 kinase-cyclin D1 complex. Carcinogenesis 20 193-198.

Gregory CW, Johnson RT Jr, Presnell SC, Mohler JL \& French FS 2001 Androgen receptor regulation of G1 cyclin and cyclin-dependent kinase function in the CWR22 human prostate cancer xenograft. Journal of Andrology 22 537-548.

Hofmann J, Doppler W, Jakob A, Maly K, Posch L, Uberall F \& Grunicke HH 1988 Enhancement of the antiproliferative effect of cis-diaminedichloroplatinum (II) and nitrogen mustard by inhibitors of protein kinase C. International Journal of Cancer 42 382-388.

Huynh H, Larsson C, Narod S \& Pollak M 1995 Tumour suppressor activity of the gene encoding mammary-derived growth inhibitor. Cancer Research 55 2225-2231.

Huynh H, Seyam RM \& Brock GB 1998 Reduction of ventral prostate weight by finasteride is associated with suppression of insulin-like growth factor I (IGF-I), IGF-I receptor, and an increase in IGF binding protein 3. Cancer Research 58 215-218.

Kaneuchi M, Sasaki M, Tanaka Y, Sakuragi N, Fujimoto S \& Dahiya R 2003 Quercetin regulates growth of Ishikawa cells through the suppression of EGF and cyclin D1. International Journal of Oncology 22 159-164.

Kitagawa M, Higashi H, Jung HK, Suzuki-Takahashi I, Ikeda M, Tamai K, Kato J, Segawa K, Yoshida E, Nishimura S \& Taya Y 1996 The consensus motif for phosphorylation by cyclin D1-Cdk4 is different from that for phosphorylation by cyclin A/E-Cdk2. EMBO Journal 15 7060-7069.

Kuwajerwala N, Cifuentes E, Gautam S, Menon M, Barrack ER \& Reddy GP 2002 Resveratrol induces prostate cancer cell entry into S phase and inhibits DNA synthesis. Cancer Research 62 2488-2492.

Lee MH \& Yang HY 2001 Negative regulators of cyclin-dependent kinases and their role in cancers. Cellular and Molecular Life Sciences 58 1907-1922.

Lu R \& Serrero G 1999 Resveratrol, a natural product derived from grape, exhibits antiestrogenic activity and inhibits the growth of human breast cancer cells. Journal of Cellular Physiology 179 297-304.

Lu S, Tsai SY \& Tsai MJ 1997 Regulation of androgen-dependent prostatic cancer cell growth: androgen regulation of CDK2, CDK4, and CKI p16 genes. Cancer Research 57 4511-4516.

Lu S, Liu M, Epner DE, Tsai SY \& Tsai MJ 1999 Androgen regulation of the cyclin-dependent kinase inhibitor p21 gene through an androgen response element in the proximal promoter. Molecular Endocrinology 13 376-384.

Maggiolini M, Bonofiglio D, Marsico S, Panno ML, Cenni B, Picard D \& Ando S 2001 Estrogen receptor $\alpha$ mediates the proliferative but not the cytotoxic dose-dependent effects of two major phytoestrogens on human breast cancer cells. Molecular Pharmacology 60 595-602.

Morand C, Crespy V, Manach C, Besson C, Demigne C \& Remesy C 1998 Plasma metabolites of quercetin and their antioxidant properties. American Journal of Physiology 275 R211-R219.

Morand C, Manach C, Crespy V \& Remesy C 2000 Quercetin 3-O-beta-glucoside is better absorbed than other quercetin forms and is not present in rat plasma. Free Radical Research 33 667-676.

Murphy WM, Soloway MS \& Barrows GH 1991 Pathologic changes associated with androgen deprivation therapy for prostate cancer. Cancer 68 821-828. 
Ngan ES, Hashimoto Y, Ma ZQ, Tsai MJ \& Tsai SY 2003 Overexpression of $\mathrm{Cdc} 25 \mathrm{~B}$, an androgen receptor coactivator, in prostate cancer. Oncogene 22 734-739.

Nickerson T, Pollak M \& Huynh H 1998 Castration-induced apoptosis in the rat ventral prostate is associated with increased expression of genes encoding insulin-like growth factor binding proteins 2, 3, 4 and 5. Endocrinology 1392 807-810.

Pan W, Sun T, Hoess R \& Grafstrom R 1998 Defining the minimal portion of the retinoblastoma protein that serves as an efficient substrate for cdk4 kinase/cyclin D1 complex. Carcinogenesis 19 765-769.

Peter M, Le Peuch C, Labbe JC, Meyer AN, Donoghue DJ \& Doree M 2002 Initial activation of cyclin-B1-cdc2 kinase requires phosphorylation of cyclin B1. EMBO Reports 3 551-556.

Petre CE, Wetherill YB, Danielsen M \& Knudsen KE 2002 Cyclin D1: mechanism and consequence of androgen receptor co-repressor activity. Journal of Biological Chemistry 277 2207-2215.

Porter DC, Zhang N, Danes C, McGahren MJ, Harwell RM, Faruki S \& Keyomarsi K 2001 Tumor-specific proteolytic processing of cyclin E generates hyperactive lower molecular-weight forms. Molecular and Cellular Biology 21 6254-6269.

Ranelletti FO, Ricci R, Larocca LM, Maggiano N, Capelli A, Scambia G, Benedetti-Panici P, Mancuso S, Rumi C \& Piantelli M 1992 Growth-inhibitory effect of quercetin and presence of type-II estrogen-binding sites in human colon-cancer cell lines and primary colorectal tumors. International Journal of Cancer 50 486-492.

Rittmaster RS 1994 Drug therapy - finasteride. New England Journal of Medicine 330 120-125.

Roovers K \& Assoian RK 2000 Integrating the MAP kinase signal into the G1 phase cell cycle machinery. Bioessays 22 818-826.

Sherr CJ 1996 Cancer cell cycles. Science 274 1672-1677.

Steinmetz KA \& Potter JD 1991 Vegetables, fruit, and cancer. I. Epidemiology. Cancer Causes Control 2 325-357.
Stone S, Dayananth P, Jiang P, Weaver-Feldhaus JM, Tavtigian SV, Cannon-Albright L \& Kamb A 1995 Genomic structure, expression and mutational analysis of the P15 (MTS2) gene. Oncogene 11 987-991.

Stoner E 1994 Three-year safety and efficacy data on the use of finasteride in the treatment of benign prostatic hyperplasia. Urology 43 284-294.

The Finasteride Study Group 1993 Finasteride in the treatment of benign prostatic hyperplasia. Prostate 22 291-299.

Vidal A \& Koff A 2000 Cell-cycle inhibitors: three families united by a common cause. Gene 247 1-15.

Walsh S, Margolis SS \& Kornbluth S 2003 Phosphorylation of the cyclin b1 cytoplasmic retention sequence by mitogen-activated protein kinase and plx. Molecular Cancer Research 1 280-289.

Wei YQ, Zhao X, Kariya Y, Fukata H, Teshigawara K \& Uchida A 1994 Induction of apoptosis by quercetin: involvement of heat shock protein. Cancer Research 54 4952-4957.

Yam CH, Fung TK \& Poon RY 2002 Cyclin A in cell cycle control and cancer. Cellular and Molecular Life Sciences 59 1317-1326.

Yamamoto A, Hashimoto Y, Kohri K, Ogata E, Kato S, Ikeda K \& Nakanishi M 2000 Cyclin E as a coactivator of the androgen receptor. Journal of Cell Biology 150 873-880.

Yang CS \& Wang ZY 1993 Tea and cancer. Journal of the National Cancer Institute 85 1038-1049.

Yoshida M, Yamamoto M \& Nikaido T 1992 Quercetin arrests human leukemic T-cells in late G1 phase of the cell cycle. Cancer Research 52 6676-6681.

Received 8 January 2004

Accepted 5 March 2004 